\title{
KONSEP PERBAIKAN ARAH ALIRAN DRAINASE MENURUT KONSULTAN PERENCANA
}

\author{
Erwin Nainggolan \\ Jurusan/Program Studi Teknik Sipil, Fakultas Teknik, Universitas Palangka Raya \\ Jln. Hendrik Timang, Palangka Raya, e-mail: erwin.nainggolan11.04@gmail.com \\ I Made Kamiana \\ Jurusan/Program Studi Teknik Sipil, Fakultas Teknik, Universitas Palangka Raya \\ Jln. Hendrik Timang, Palangka Raya, e-mail: kamianamade62@ gmail.com \\ Raden Haryo Saputra \\ Jurusan/Program Studi Teknik Sipil, Fakultas Teknik, Universitas Palangka Raya \\ Jln. Hendrik Timang, Palangka Raya, e-mail: den_yo_saputra@yahoo.com
}

\begin{abstract}
The junction of drainage canals on Jalan Yos Sudarso-Jalan Bukit Keminting Palangka Raya City, is a junction between secondary drainage channels and primary drainage channels. Based on the results of discharge measurements, secondary drainage channels on Jalan Yos Sudarso-Perumahan Dosen and on Jalan Yos Sudarso-Taman Kuliner actually received flow fro $m$ the primary channel on Jalan Yos Sudarso III and partly from the primary drainase channel on Jalan Bukit Keminting. The problem of the direction of drainage channel flow needed to be examined in order to find out the concepts of improvement according to the perceptions of the Planning Consultant. This perception data collection was done by distributing questionnaire. To make it easier for the Planning Consultant to understand the questionnaire, the questionnaire should be accompanied by supporting data, namely the drainage channel layout, drainage channel profile, and drainage discharge. which was tested with a validity test and a reliability test. The questionnaire was tested by using validity and reliability testing. The selection of respondents used purposive sampling, namely planning consultants who live in Palangka Raya City. Determination of the number of samples used the solvin technique. Data analysis was performed using descriptive techniques with the help of the SPSS version 25 program. According to the Planning Consultant's perceptions, there were six concepts that could be applied to improve the direction of drainage canals on Jalan Yos Sudarso-Jalan Bukit Keminting. If sorted according to the mean value, the concept of improvement such as follows: deepening of channels, strengthening of channel walls, repairing cliff slopes, repairing network schemes, making complementary buildings and deepening + widening.
\end{abstract}

Keywords: concept of improvement, direction of drainage flow, consultant planners

Abstrak: Pertemuan saluran drainase di Jalan Yos Sudarso-Jalan Bukit Keminting Kota Palangka Raya, merupakan pertemuan antara saluran drainase sekunder dengan saluran drainase primer. Berdasarkan hasil pengukuran debit, saluran drainase sekunder di Jalan Yos Sudarso-Perumahan Dosen dan di Jalan Yos SudarsoTaman Kuliner justru menerima aliran dari saluran primer di Jalan Yos Sudarso III dan sebagian lagi dari saluran drainase primer di Jalan Bukit Keminting. Permasalahan arah aliran saluran drainase ini perlu diteliti dengan tujuan untuk mengetahui konsep-konsep perbaikannya menurut persepsi Konsultan Perencana. Pengumpulan data persepsi ini dilakukan dengan penyebaran kuesioner. Agar Konsultan Perencana lebih mudah dalam memahami kuesioner, maka kuesioner dilampiri dengan data pendukung, yaitu lay out saluran drainase, profil saluran drainase, dan debit drainase. Pengujian kuesioner dilakukan dengan uji validitas dan uji reliabilitas. Pemilihan responden menggunakan Purposive Sampling yaitu konsultan perencana yang berdomisili di Kota Palangka Raya. Penentuan jumlah sampel menggunakan Teknik Solvin. Analisis data dilakukan dengan teknik deskriptif dengan bantuan program SPSS versi 25. Menurut persepsi Konsultan Perencana, terdapat enam konsep yang dapat diterapkan untuk memperbaiki arah aliran saluran drainase di Jalan Yos Sudarso-Jalan Bukit Keminting. Apabila diurutkan berdasarkan nilai mean, konsep perbaikan itu sebagai berikut: pendalaman saluran, perkuatan dinding saluran, perbaikan kemiringan lereng tebing, perbaikan skema jaringan, pembuatan bangunan pelengkap dan pendalaman pelebaran.

Kata kunci: konsep perbaikan, arah aliran drainase, konsultan perencana 


\section{PENDAHULUAN}

\section{Latar belakang}

Palangka Raya merupakan ibu kota Provinsi Kalimantan Tengah. Kota Palangka Raya memiliki luas wilayah $2.399,50 \mathrm{~km}^{2}$ (239.950 ha), kondisi topografi terdiri dari tanah datar dengan kemiringan $0 \%-8 \%$ dan bukit dengan kemiringan kurang dari $40 \%$ (Anonim, 2018).

Setiap musim hujan, di beberapa kawasan permukiman Kota Palangka Raya sering terjadi banjir dan genangan. Oleh karena itu, di Kota Palangka Raya masih sangat diperlukan adanya pembangunan, pemeliharaan dan perbaikan saluran-saluran drainase beserta gorong-gorong sebagai bangunan pelengkap.

Konstruksi jaringan saluran drainase pada sistem drainase perkotaan di Kota Palangka Raya, sebagian sudah dibangun dan sebagian ada yang belum dibangun. Dalam Kamiana dan Jaya (2019) dijelaskan bahwa dinding saluran saluran drainase yang sudah dibangun itu, ada yang sudah dilining dan ada juga yang belum dilining.

Beberapa kawasan permukiman di Kota Palangka Raya yang sering mengalami banjir dan genangan, antara lain: (i) kawasan permukiman di sekitar Jalan Taurus (Noperdie dkk, 2018), (ii) kawasan permukiman di sekitar Jalan Sangga Buana II (Agustulusnu dkk, 2019), (iii) dan kawasan permukiman di sekitar Jalan Seth Adji (Jailani dkk, 2019). Selain yang telah disebutkan tadi, kawasan-kawasan permukiman di sekitar Jalan Yos Sudarso-Bukit Keminting Kota Palangka Raya juga sering mengalami banjir dan genangan. Saluran drainase Jalan Yos Sudarso dan saluran drainase Jalan Bukit Keminting merupakan pertemuan antara saluran sekunder dan saluran primer. Saluran drainase Jalan Yos Sudarso induk merupakan saluran sekunder sedangkan saluran darinase Jalan Yos Sudarso III dan saluran drainase Jalan Bukit Keminting merupakan saluran primer.

Berdasarkan hasil pengukuran debit, saluran sekunder (saluran Jalan Yos SudarsoPerumahan Dosen dan saluran Jalan Yos Sudarso-Taman Kuliner) menerima aliran dari saluran primer Jalan Yos Sudarso III dan sebagian lagi dari saluran drainase primer Jalan Bukit Keminting. Arah aliran saluran drainase tersebut tidak sesuai dengan arah aliran saluran drainase umumnya seperti dijelaskan dalam Subarkah (1980) yaitu saluran drainase primer berfungsi untuk menampung dan mengalirkan air buangan dari saluran sekunder serta limpasan permukaan yang ada pada daerah tangkapan saluran tersebut; saluran drainase sekunder berfungsi untuk menampung air drainase tersier serta limpasan permukaan yang ada untuk diteruskan ke drainase primer.

Dengan adanya permasalahan arah aliran pada pertemuan saluran drainase di Jalan Yos Sudarso-Jalan Bukit Keminting maka perlu dilakukan penelitian untuk mengetahui konsep perbaikannya.

\section{Rumusan masalah}

Berdasarkan latar belakang masalah diatas, permasalahan penelitian ini dirumuskan sebagai berikut: bagaimana konsep perbaikan arah aliran pada pertemuan drainase di Jalan Yos Sudarso-Jalan Bukit Keminting Kota Palangka Raya?

\section{Batasan masalah}

Konsep perbaikan arah aliran saluran drainase yang dimaksud dalam penelitian ini adalah konsep perbaikan menurut persepsi Konsultan Perencana yang berdomisili di Kota Palangka Raya.

\section{Tujuan penelitian}

Penelitian ini bertujuan untuk mengetahui konsep perbaikan arah aliran saluran drainase pada pertemuan saluran drainase di Jalan Yos Sudarso-Jalan Bukit Keminting Kota Palangka Raya menurut persepsi Konsultan Perencana.

\section{Manfaat penelitian}

Adapun beberapa manfaat dari penelitian ini:

1. Bagi akademik

Penelitian ini diharapkan dapat memberikan informasi bagi yang mendalami bidang drainase khususnya mengenai beberapa konsep perbaikan arah aliran pada saluran drainase.

2. Bagi instansi terkait 
Penelitian ini diharapkan memberikan rekomendasi kepada instansi terkait dan para pihak yang berkepentingan dalam melakukan perbaikan drainase di Kota Palangka Raya, khususnya pada pertemuan drainase Jalan Yos Sudarso dan drainase Jalan Bukit Keminting.

3. Bagi masyarakat

Penelitian ini diharapkan dapat memberikan informasi mengenai beberapa konsep perbaikan arah aliran saluran drainase.

\section{TINJAUAN PUSTAKA}

\section{Pengertian drainase}

Menurut Suripin (2004) pengertian drainase secara umum adalah suatu tindakan teknis untuk mengurangi kelebihan air baik yang berasal dari air hujan, rembesan, maupun kelebihan air irigasi dari suatu lahan atau kawasan sehingga fungsi lahan atau kawasan tersebut tidak terganggu.

\section{Jenis saluran drainase}

Menurut Anonim (2014), saluran drainase dapat dibedakan menjadi tiga:

1. Saluran drainase primer adalah saluran drainase yang menerima air dari sakuran sekunder dan meneruskannya ke badan air penerima.

2. Saluran drainase sekunder adalah saluran drainase yang menerima air dari saluran tersier dan meneruskannya ke saluran primer.

3. Saluran drainase tersier adalah saluran yang menerima air dari saluran penangkap dan meneruskannya ke saluran sekunder.

\section{Fungsi saluran drainase}

Menurut Kodoatie (2003), fungsi drainase sebagai berikut:

1. Membebaskan suatu wilayah (terutama yang padat dari permukiman) dari genangan air, erosi dan banjir.

2. Karena aliran lancar maka drainase juga berfungsi memperkecil resiko kesehatan lingkungan bebas dari malaria (nyamuk) dan penyakit lainnya.

3. Kegunaan tanah permukiman padat akan menjadi lebih baik terhindar dari kelembaban.

4. Dengan sistem drainase yang baik tataguna lahan dapat dioptimalkan dan juga memperkecil kerusakan-kerusakan struktur tanah untuk jalan dan bangunan lainnya.

\section{Konsep perbaikan arah aliran saluran drainase}

Beberapa konsep perbaikan yang dapat dilakukan untuk memperbaiki arah aliran saluran drainase:

1. Pendalaman saluran

Kegiatan menggali tanah/sedimentasi yang berada di dasar saluran yang dapat mengganggu kinerja saluran (Sinaga dan Harahap, 2016).

2. Pelebaran saluran

Pelebaran terhadap drainase dilakukan sebagai upaya untuk meningkatkan kapasitas drainase yang sudah tidak mampu menampung debit rencana yang mengalir (Fairizi, 2015).

3. Perkuatan dinding saluran

Perkuatan dinding saluran merupakan perbaikan yang bertujuan untuk mengatasi erosi yang menyebabkan longsoran pada dinding saluran (Anonim, 2013).

4. Perbaikan skema jaringan

Penambahan jaringan saluran merupakan penambahan saluran cabang untuk dapat menampung air saluran sebelum diteruskan ke saluran utama. Penambahan saluran bertujuan untuk meminimalisir kapasitas tampungan pada saluran yang ada sebelumnya (Lengkong dkk, 2018).

5. Pembuatan bangunan pelengkap Bangunan pelengkap saluran drainase untuk sebagai pendukung sistem drainase dengan fungsi-fungsi tertentu (Suripin, 2004).

6. Kolam detensi

Pada kolam detensi air ditampung sementara waktu kemudian dialirkan kembali ke hilir badan air ketika puncak banjir telah lewat (Harmani dan Soemantoro, 2017).

7. Pompa

Sistem drainase yang tidak dapat sepenuhnya mengandalkan gravitasi sebagai faktor pendorong, maka perlu dilengkapi dengan stasiun pompa (Sudjatmiko dkk, 2016).

\section{METODE PENELITIAN}

\section{Umum}

Metode penelitian adalah suatu cara ilmiah untuk mendapatkan data dengan tujuan dan 
kegunaan tertentu (Sugiyono, 2010). Terdapat beberapa metode penelitian yang dapat digunakan dalam melakukan suatu penelitian, antara lain: metode eksperimen dan metode survei (Sugiyono, 2010). Dalam penelitian ini, metode penelitian yang digunakan adalah metode survei.

\section{Lokasi dan waktu penelitian}

Penelitian ini dilakukan pada pertemuan saluran drainase di Jalan Yos Sudarso-Jalan Bukit Keminting Kota Palangka Raya (Gambar 1). Waktu penelitian dimulai dari bulan Desember 2019 sampai dengan bulan Maret 2020.

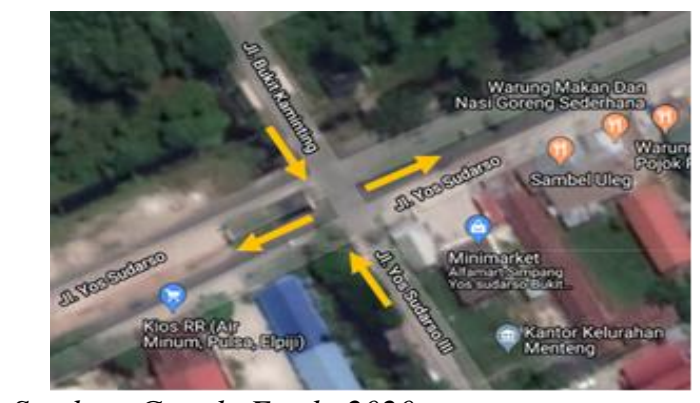

Sumber: Google Earth, 2020

Gambar 1. Lokasi penelitian

\section{Data penelitian}

Data utama yang digunakan dalam penelitian ini adalah berupa data persepsi Konsultan Perencana mengenai konsep perbaikan arah aliran saluran drainase. Sedangkan data pendukungnya terdiri dari: lay out saluran drainase, data profil saluran, data debit, data jumlah populasi Konsultan Perencana, dan peta lokasi.

\section{Tahapan penelitian}

Penelitian ini dilakukan dalam lima tahap:

1. Tahap Pertama

Tahap pertama penelitian ini merupakan tahap pendahuluan. Tahap pendahuluan terdiri dari penyusunan latar belakang, rumusan masalah, batasan masalah, tujuan penelitian dan manfaat penelitian.

\section{Tahap kedua}

Tahap kedua penelitian ini merupakan tahapan studi literatur. Tahap ini akan menghasilkan hasil akhir berupa Tinjauan Pustaka.

3. Tahap ketiga

Tahap ketiga penelitian ini merupakan tahap pengumpulan data. Kegiatan- kegiatan yang dilakukan dalam tahap ini.
a. Umum
b. Lokasi dan waktu penelitian
c. Data penelitian: data primer dan data sekunder
d. Tahapan penelitian
e. Teknik pengumpulan data: penyebaran Kuesioner

4. Tahap keempat

Tahap keempat merupakan tahap analisis data: uji validitas, uji reliabilitas dan analisis deskriptif.

5. Tahap kelima

Tahap kelima penelitian ini merupakan tahap pengambilan kesimpulan dan saran, penulisan Jurnal dan penulisan Tugas Akhir dari hasil penelitian. Hasil akhir dari tahap kelima ini berupa Kesimpulan, Saran, Jurnal dan Laporan Tugas Akhir.

\section{Teknik pengumpulan data}

Teknik pengumpulan data merupakan cara mendapatkan data yang memenuhi standar data yang telah ditetapkan (Sugiyono, 2010). Dalam penelitian ini, teknik pengumpulan data dilakukan dengan penyebaran kuesioner.

Penyebaran kuesioner dilakukan untuk mendapatkan data persepsi Konsultan Perencana mengenai konsep perbaikan arah aliran saluran drainase. Agar Konsultan Perencana lebih mudah dalam memahami kuesioner, maka kuesioner dilampiri dengan data pendukung, yaitu: lay out saluran drainase, profil saluran drainase, dan debit drainase.

\section{Teknik sampling}

Pengambilan sampel dalam penelitian ini dilakukan berdasarkan metode Purposive Sampling. Dalam Sugiyono (2017) dijelaskan bahwa metode Purposive Sampling adalah cara penentuan sampel berdasarkan pertimbangan tertentu.

Sampel yang digunakan dalam penelitian ini adalah Konsultan Perencana yang berdomisili di Kota Palangka Raya. Dasar pertimbangannya, Konsultan Perencana yang berdomisili di Kota Palangka Raya dianggap lebih memahami permasalahan saluran drainase yang menjadi fokus penelitian ini. Jumlah sampel dalam penelitian ini ditentukan dengan Teknik Solvin (Sugiyono, 2016). 


\section{Analisis data}

Menurut Sugiyono (2017), metode deskriptif merupakan metode yang bertujuan untuk mengetahui keberadaan variabel mandiri, baik hanya pada satu variabel atau lebih (variabel yang berdiri sendiri atau variabel bebas) tanpa membuat perbandingan variabel itu sendiri dan mencari hubungan dengan variabel lain.

Dalam penelitian ini, metode deskriptif digunakan untuk menganalisis konsep perbaikan arah aliran saluran drainase yang disetujui dan yang tidak disetujui oleh Konsultan Perencana.

Pemberian skor yang digunakan dalam kuesioner adalah dalam bentuk skala likert (Sugiyono, 2016), dengan score rating scale sebagai berikut: 1 sangat tidak setuju; 2 kurang setuju; 3 cukup setuju; 4 sangat setuju.

Analisis konsep perbaikan arah aliran saluran drainase dilakukan dengan meninjau nilai parameter data persepsi, yaitu: mean, standar deviasi dan variance (Quadratullah, 2014).

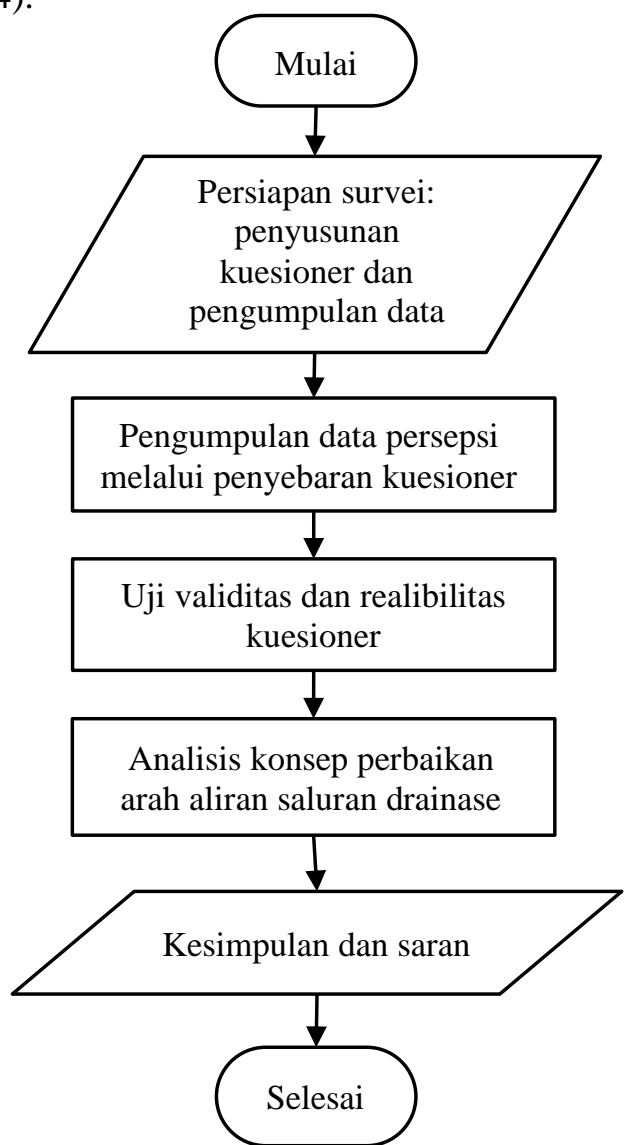

Gambar 2. Bagan alir penelitian

\section{HASIL DAN PEMBAHASAN}

\section{Debit dan arah aliran saluran drainase}

Debit dan arah aliran saluran drainase, yang merupakan data pendukung dalam penelitian ini, telah dikumpulkan dari tahapan penelitian sebelumnya. Hasil pengukuran debit dapat dilihat pada Tabel 1.

Tabel 1. Debit saluran

\begin{tabular}{|c|c|c|c|c|}
\hline \multirow[b]{2}{*}{$\begin{array}{l}\text { Tanggal } \\
\text { Pengu } \\
\text { kuran }\end{array}$} & \multicolumn{4}{|c|}{ Debit (m³/detik) } \\
\hline & $\begin{array}{c}\text { Jl. Yos } \\
\text { Sudar } \\
\text { so III }\end{array}$ & $\begin{array}{c}\text { Jl. Yos } \\
\text { Sudarso } \\
\text {-Taman } \\
\text { Kuliner }\end{array}$ & $\begin{array}{l}\text { Jl. Bukit } \\
\text { Kemin } \\
\text { ting }\end{array}$ & $\begin{array}{c}\text { Jl. Yos } \\
\text { Sudarso- } \\
\text { Perumaha } \\
\text { n Dosen }\end{array}$ \\
\hline $\begin{array}{c}\text { 27-Jan- } \\
20\end{array}$ & 0.119 & 0.072 & 0.040 & 0.087 \\
\hline $\begin{array}{c}\text { 28-Jan- } \\
20\end{array}$ & 0.846 & 0.294 & 0.179 & 0.733 \\
\hline $\begin{array}{c}\text { 29-Jan- } \\
20\end{array}$ & 0.719 & 0.347 & 0.182 & 0.555 \\
\hline $\begin{array}{c}\text { 30-Jan- } \\
20\end{array}$ & 0.274 & 0.226 & 0.266 & 0.314 \\
\hline $\begin{array}{c}\text { 31-Jan- } \\
20\end{array}$ & 0.209 & 0.152 & 0.122 & 0.180 \\
\hline $\begin{array}{c}\text { 1-Feb- } \\
20\end{array}$ & 0.149 & 0.082 & 0.041 & 0.109 \\
\hline $\begin{array}{c}10- \\
\text { Feb-20 }\end{array}$ & 0.586 & 0.314 & 0.224 & 0.498 \\
\hline $\begin{array}{c}11- \\
\text { Feb-20 }\end{array}$ & 0.242 & 0.197 & 0.216 & 0.262 \\
\hline $\begin{array}{c}12- \\
\text { Feb-20 }\end{array}$ & 0.180 & 0.123 & 0.098 & 0.156 \\
\hline $\begin{array}{c}13- \\
\text { Feb-20 }\end{array}$ & 0.116 & 0.069 & 0.030 & 0.075 \\
\hline $\begin{array}{c}18- \\
\text { Feb-20 }\end{array}$ & 0.754 & 0.309 & 0.188 & 0.636 \\
\hline $\begin{array}{c}19- \\
\text { Feb-20 }\end{array}$ & 0.504 & 0.283 & 0.235 & 0.454 \\
\hline $\begin{array}{c}20- \\
\text { Feb-20 }\end{array}$ & 0.696 & 0.345 & 0.210 & 0.562 \\
\hline $\begin{array}{c}21- \\
\text { Feb-20 }\end{array}$ & 0.298 & 0.184 & 0.152 & 0.267 \\
\hline $\begin{array}{c}22- \\
\text { Feb-20 }\end{array}$ & 0.774 & 0.311 & 0.184 & 0.648 \\
\hline $\begin{array}{c}23- \\
\text { Feb-20 }\end{array}$ & 0.585 & 0.285 & 0.223 & 0.522 \\
\hline
\end{tabular}

Bersamaan dengan pengukuran debit yang telah dilakukan pada tahap penelitian 
sebelumnya, juga telah dilakukan pengamatan gerakan atau arah aliran dengan bantuan video.

Hasil pengamatan arah aliran saluran drainase pada setiap pengukuran debit menunjukkan bahwa arah aliran saluran drainase sekunder di Jalan Yos Sudarso-Taman Kuliner dan Jalan Yos Sudaro-Perumahan Dosen tidak mengalir ke saluran drainase primer di Jalan Bukit Keminting. Demikian juga arah aliran saluran drainase primer di Jalan Yos Sudarso III tidak mengalir ke saluran drainase primer di Jalan Bukit Keminting. Sebaliknya, sebagian dari saluran drainase primer di Jalan Bukit Keminting justru mengalir ke saluran drainase sekunder di Jalan Yos Sudarso-Taman Kuliner dan Jalan Yos Sudaro-Perumahan Dosen (lihat Gambar 3).

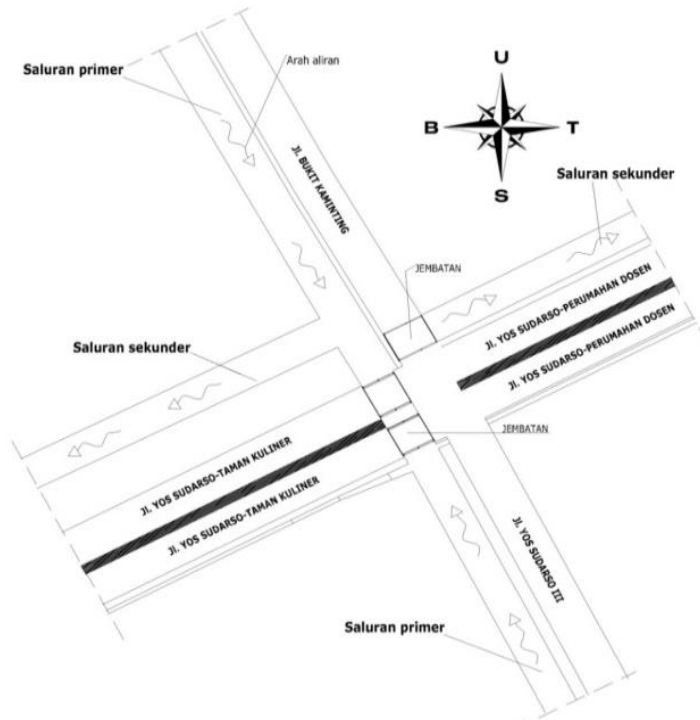

Gambar 3. Sketsa arah aliran saluran drainase

\section{Sampel dan profil responden}

Berdasarkan Teknik Solvin (Sugiyono, 2016), jumlah sampel penelitian ini ditetapkan sebanyak 48 sampel. Mengacu pada jumlah sampel ini, juga telah dilakukan penentuan nama-nama Konsultan Perencana sebagai responden penelitian berdasarkan metode purposive sampling (Sugiyono, 2017).

Profil responden penelitian berdasarkan aspek jenjang pendidikan dan pengalaman kerja sebagai Konsultan Perencana dapat dijelaskan sebagai berikut: (i) berpendidikan S1 Teknik Sipil sebanyak $87 \%$, dan berpendidikan S2 Teknik Sipil sebanyak 13\%; (ii) memiliki pengalaman kerja di bawah 5 tahun sebanyak $42 \%$, antara 5-10 tahun sebanyak $25 \%$, antara
10-15 tahun sebanyak 29\%, dan di atas 15 tahun sebanyak $2 \%$.

\section{Uji validitas dan uji reliabilitas instrumen}

Uji validitas kuesioner mengenai konsep perbaikan dilakukan dengan metode Korelasi Product Moment Pearson, derajat kebebasan (dk) ditentukan persamaan (Sugiyono, 2016):

$\mathrm{dk}=\mathrm{n}-2$

dengan $\mathrm{dk}=$ derajat kebebasan, $\mathrm{n}=$ jumlah sampel.

Taraf signifikan atau $\alpha$ ditetapkan sebesar 5\% (Sugiyono, 2016). Dengan $\mathrm{dk}=46 \mathrm{dan} \alpha=$ $5 \%$, didapat $r$ tabel (Sugiyono, 2016) $=0,291$. Suatu instrument dikatakan valid jika $\mathrm{r}_{\text {hitung }}>$ $\mathrm{r}_{\text {tabel }}$ (Sugiyono, 2016). Hasil uji valisitas dapat dilihat pada Tabel 2. Berdasarkan Tabel 2 dapat disimpulkan bahwa instrumen ini valid.

Tabel 2. Hasil uji validitas konsep perbaikan

\begin{tabular}{cccc}
\hline No & Konsep Perbaikan & $\mathrm{r}_{\text {hitung }}$ & $\mathrm{r}_{\text {tabel }}$ \\
\hline 1 & 0,723 & 0,291 \\
2 & $\begin{array}{l}\text { Pendalaman } \\
\text { Pendalaman + }\end{array}$ & 0,648 & 0,291 \\
& $\begin{array}{l}\text { Pelebaran } \\
\text { Pendalaman + } \\
\text { pelebaran +pompa } \\
\text { Pendalaman + }\end{array}$ & 0,562 & 0,291 \\
4 & $\begin{array}{l}\text { pelebaran+kolam } \\
\text { detensi }\end{array}$ & 0,507 & 0,291 \\
5 & $\begin{array}{l}\text { Perkuatan dinding } \\
\text { saluran }\end{array}$ & 0,739 & 0,291 \\
6 & $\begin{array}{l}\text { Perbaikan kemiringan } \\
\text { lereng tebing }\end{array}$ & 0,602 & 0,291 \\
7 & $\begin{array}{l}\text { Pembuatan bangunan } \\
\text { pelengkap }\end{array}$ & 0,652 & 0,291 \\
8 & $\begin{array}{l}\text { Perbaikan skema } \\
\text { jaringan }\end{array}$ & 0,586 & 0,291 \\
\hline Sumber: Analisis Data (2020) &
\end{tabular}

Uji reliabilitas kuesioner dilakukan dengan teknik Alpha Cronbach (Sugiyono, 2016). Apabila nilai Alpha Cronbach > 0,6 maka instrument atau kuesioner dinyatakan reliabel (Siregar, 2010). Hasil uji reliabilitas dapat dilihat pada Tabel 3. Berdasarkan Tabel 3 dapat disimpulkan instrumen penelitian ini reliabel.

Tabel 3. Hasil uji reliabilitas konsep perbaikan

\begin{tabular}{ccc}
\hline Kategori & $\begin{array}{c}\text { Nilai } \\
\text { Cronbach } \\
\text { Alpha }\end{array}$ & Kesimpulan \\
\hline $\begin{array}{c}\text { Konsep } \\
\text { perbaikan }\end{array}$ & 0,753 & Reliabel \\
\hline \multicolumn{2}{l}{ Sumber: Analisis Data (2020) }
\end{tabular}




\section{Konsep perbaikan arah aliran saluran drainase}

Data persepsi Konsultan Perencana mengenai konsep perbaikan arah aliran saluran drainase pada pertemuan drainase di Jalan Yos Sudarso-Jalan Bukit Keminting, telah dianalisis secara deskriptif dengan mencari nilai mean, variance dan standar deviasi dari setiap item konsep perbaikan. Hasilnya tercantum pada Tabel 4.

Tabel 4. Hasil uji deskriptif konsep perbaikan

\begin{tabular}{|c|c|c|c|c|}
\hline No & $\begin{array}{c}\text { Konsep } \\
\text { Perbaikan }\end{array}$ & Mean & $\begin{array}{l}\text { Standar } \\
\text { Deviasi }\end{array}$ & $\begin{array}{c}\text { Varian } \\
\text { ce }\end{array}$ \\
\hline 1 & Pendalaman & 3,729 & 0,449 & 0,202 \\
\hline 2 & $\begin{array}{l}\text { Perkuatan } \\
\text { dinding saluran } \\
\text { Perbaikan }\end{array}$ & 3,625 & 0,606 & 0,367 \\
\hline 3 & $\begin{array}{l}\text { kemiringan } \\
\text { lereng tebing }\end{array}$ & 3,583 & 0,539 & 0,291 \\
\hline 4 & $\begin{array}{l}\text { Perbaikan } \\
\text { skema jaringan } \\
\text { Pembuatan }\end{array}$ & 3,562 & 0,769 & 0,592 \\
\hline 5 & $\begin{array}{l}\text { bangunan } \\
\text { pelengkap }\end{array}$ & 3,521 & 0,652 & 0,425 \\
\hline 6 & $\begin{array}{l}\text { Pendalaman }+ \\
\text { pelebaran }+ \\
\text { pompa }\end{array}$ & 2,354 & 0,911 & 0,829 \\
\hline 7 & $\begin{array}{l}\text { Pendalaman }+ \\
\text { pelebaran }+ \\
\text { kolam detensi }\end{array}$ & 2,333 & 0,724 & 0,525 \\
\hline 8 & $\begin{array}{l}\text { Pendalaman + } \\
\text { pelebaran }\end{array}$ & 3,271 & 0,818 & 0,670 \\
\hline
\end{tabular}

Sumber: Analisis Data (2020)

Untuk meninjau konsep perbaikan yang disetujui atau tidak disetujui oleh Konsultan Perencana, maka nilai mean pada Tabel 4 dibandingkan dengan nilai mean pada Tabel 5.

Tabel 5. Interpretasi nilai Mean

\begin{tabular}{cc}
\hline Interval Mean & Kriteria \\
\hline $1,00 \mathrm{~s} / \mathrm{d} 1,74$ & Sangat tidak setuju \\
$1,75 \mathrm{~s} / \mathrm{d} 2,49$ & Kurang setuju \\
$2,50 \mathrm{~s} / \mathrm{d} 3,25$ & Cukup setuju \\
$3,26 \mathrm{~s} / \mathrm{d} 4,00$ & Sangat setuju \\
\hline Sumber: Sugiyono (2010)
\end{tabular}

Berdasarkan perbandingan nilai mean pada Tabel 4 dan Tabel 5, kemudian diurut berdasarkan besarnya nilai mean dari tiap-tiap konsep perbaikan, maka konsep-konsep perbaikan yang disetujui oleh Konsultan Perencana: (i) pendalaman, (ii) perkuatan dinding saluran, (iii) perbaikan kemiringan lereng tebing, (iv) perbaikan skema jaringan, (v) pembuatan bangunan pelengkap dan (vi) pendalaman + pelebaran

Sedangkan konsep perbaikan arah aliran saluran drainase yang tidak disetujui Konsultan Perencana: (i) pendalaman + pelebaran + pompa, (ii) pendalaman + pelebaran + kolam detensi.

\section{KESIMPULAN DAN SARAN}

\section{Kesimpulan}

Menurut persepsi Konsultan Perencana, ada lima konsep yang dapat digunakan untuk memperbaiki arah aliran pada pertemuan saluran drainase di Jalan Yos Sudarso-Jalan Bukit Keminting. Apabila diurutkan berdasarkan nilai mean, konsep perbaikan itu sebagai berikut: pendalaman, perkuatan dinding saluran, perbaikan kemiringan lereng tebing, perbaikan skema jaringan, dan pembuatan bangunan pelengkap dan pendalaman + pelebaran.

\section{Saran}

Apabila konsep-konsep perbaikan arah aliran saluran drainase menurut perspsi Konsultan Perencana ini diterapkan, maka perlu disertai dengan perencanaan teknis rinci, terutama dalam penentuan lokasi perbaikan skema jaringan dan penentuan lokasi-lokasi pembangunan maupun perbaikan bangunan pelengkap.

\section{DAFTAR PUSTAKA}

Agustulusnu, Kamiana, I.M., Jaya, A.R., (2019). "Evaluasi Dan Perencanaan Saluran Drainase Di Jalan Sangga Buana II Kota Palangka Raya". Info Teknik, Vol. 20 (2), hal 221-223

Anonim (2014). Penyelenggaran Sistem Drainase Perkotaan. Departemen Pekerjaan Umum, Jakarta.

Anonim (2013). Kriteria Perencanaan Bagian Saluran. Departemen Pekerjaan Umum, Jakarta. 
Anonim (2018). Kota Palangka Raya dalam Angka Tahun 2018. Badan Pusat Statistik, Palangka Raya.

Fairizi, D (2015). “Analisis dan Evaluasi Saluran Drainase Pada Kawasan Perumnas Talang Kelapa Di Subdas Lambidaro Kota Palembang". Jurnal Teknik Sipil dan Lingkungan, Vol.3 (1), hal. 764

Harmani, E., Soemantoro, M. (2015). "Kolam Retensi Sebagai Alternatif Pengendali Banjir". Jurnal Teknik Sipil, Vol 1(1), hal. 75

Hasmar, H (2011). Drainase Terapan. UII Press, Yogyakarta.

Jailani, M., Nomeritae, Jaya, A.R (2019). "Kajian Saluran Drainase di Daerah Jalan Seth Adji Kota Palangka Raya (Zona A)". Jurnal Teknika, Vol 3 (1). hal 96

Kamiana, I.M., Jaya, A.R (2019). "Koefisien Manning Saluran Drainase Di Ruas Jalan Bapuyu Dan Jalan Lele Kota Palangka Raya" Prosiding SNST ke-10, Vol 1 (1), hal 39-41

Kodoatie, R. J (2003). Manajemen dan

Lengkong, J. C., Sumarauw, J. S. F., Wuisan, E.M (2018). "Penataan Sistem Saluran Drainase di Kompleks Perumahan Minanga Permai Kelurahan Malalayang Dua Kecanatann Malalayang Kota Manado". Jurnal Sipil Statik, Vol.6 (5), hal. 337

Noperdie, D., Kamiana, I.M., Ariati (2018). "Perencanaan Teknis Saluran Drainase Tertutup Di Sisi Kiri-Kanan Jalan Pada Kawasan Permukiman (Studi Kasus Jalan Taurus Kawasan Permukiman Amaco Kota Palangka Raya)". Jurnal Proteksi, Vol 4 (1), hal 1-6

Quadratullah, M.F (2014). Statistika Terapan (Teori, Contoh Kasus, dan Aplikasi dengan SPSS). Andi, Yogyakarta.

Rekayasa Infrastruktur. Pustaka Pelajar, Yogyakarta.

Sinaga, R. M., Harahap, R (2016). "Analisis Sistem Saluran Drainase Pada Jalan Perjuangan Medan". Jurnal Education Building, Vol.2 (2), hal. 49
Siregar, S (2010).Statistika Deskriptif untuk Penelitian. PT Rajagrafindo Persada, Jakarta.

Subarkah, I (1980). Hidrologi Untuk Perencanaan Bangunan Air. Ide Dharma, Bandung.

Sudjatmiko, H., Bisri, M., Yuliani, E (2016). "Studi Evaluasi \& Perbaikan Sistem Drainase Di Polder Jati Pinggir Kanal Banjir Barat DKI Jakarta”. Jurnal Teknik Pengairan, Vol.7 (2), hal 218

Sugiyono (2010). Metode Penelitian Kuantitatif Kualitatif dan $R \& D$. Alfabeta, Bandung.

Sugiyono (2016). Statistika Untuk Penelitian. Alfabeta, Bandung.

Sugiyono (2017). Metode Penelitian Kuantitatif Kualitatif dan $R \& D$. Alfabeta, Bandung.

Suripin (2004). Sistem drainase perkotaan yang berkelanjutan. Andi, Yogyakarta. 